\title{
Looking from the Periphery: Some Additional Thoughts on Yulin Cave 3
}

\author{
Max Deeg
}

This contribution was conceived and developed from an encounter with a section of the pictorial programme of Yulin Cave $3 .{ }^{1}$ More specifically, it focuses on the programme of the diptych at the left and right sides of the entrance of the famous Cave 3 at Yulin (榆林) in the Hexi (河西) region. Produced during the Tangut Empire (ca. 1038-1227, in Chinese sources, known as Xixia 西夏), ${ }^{2}$ it represents as its main subjects, the Bodhisattvas Samantabhadra on the left and Mañjuśrī on the right side, who are both directed at the door and thus facing each other (figs. 9.1 and 9.2). ${ }^{3}$ Unlike the clearly recognisable main figures of the two paintings, the iconographical function of the various smaller central and peripheral elements does not seem to be completely coherent and conclusive. The paintings obviously do not refer to one single narrative programme, such as a major sütra or legend, but seem to exist as a whole and particularly with all its peripheral details — some of which I will address and discuss herea patchwork of different themes and topics added to the two central bodhisattvas, the meaningfulness of which the artist(s) probably was convinced when putting them together. Very possibly, the motifs, while originally coming from different sources, places and regions, were brought together in a local narrative context. When presenting my observations here-not as an art historian but as a textual scholar-I see my role as adding some comments on possible ways

1 In more concrete terms, the basis of this paper is a response which I gave to a paper by Michelle McCoy at the BuddhistRoad start-up conference at the Ruhr-Universität Bochum, which resulted in the publication of the present volume.

2 The cave is easily accessible virtually through the website Digital Dunhuang 數字敦煌, "Yulin Grottoes Cave o०3," accessed October 5, 2018. <https://www.e-dunhuang.com/cave/ 10.0001/0001.0002.0003>.

3 In most attempts at interpreting these two paintings, the narrative frame/periphery has been neglected in favour of the stylistic features of the main figures in the two paintings, the Bodhisattvas Mañjuśrī and Samantabhadra; see e.g. Lilla Russell-Smith, Uygur Patronage in Dunhuang: Regional Art Centres on the Northern Silk Road in the Tenth and Eleventh Centuries (Leiden, Boston: Brill, 2005), 219-220. 
of interpreting some features of the paintings rather than explaining the full iconographic programme of the two, given my restricted knowledge of the period and discipline.

I think that the pictorial content of the diptych, although not yet fully understood, represents all aspects of the title of the conference and the present volume:

1. there clearly is sacred space;

2. there is pilgrimage in the form of the two peripheral figures Xuanzang (6oo/602-664, 玄牀) and Sudhana, discussed in my comments; and

3. there is patronage and legitimation through a newly invented or, rather, newly combined narrative (or narratives) around the establishment of sacred space of the Northern Mt. Wutai (Chin. Wutai shan 五台山) of the Tangut Empire. ${ }^{4}$

Tripitaka-Xuanzang and a Proto-Xiyou ji

As a student of Buddhist textual and narrative traditions, I would like to add some rather spontaneous thoughts on the peripheral elements, which may help the art historian to contextualise the paintings in a new way. I will first focus on two rather peripheral scenes or figures and their possible meaning and function: Xuanzang, or Sanzang (三藏), i.e. Tripițaka (as he is addressed in the respective texts), in the left upper part, and the figure identified as Sudhana in the right lower part of the Samantabhadra painting (figs. 9.3 and 9.4). In the more general context of both paintings, it seems possible that Xuanzang and Sudhana are featured in the diptych because they are, from a Sinitic Buddhist point of view, the ideal or idealised travellers or pilgrims; but it is as yet unknown why and in what function they may have been inserted into the composition.

I will start with the small group of Xuanzang, the monkey and the horse (fig. 9.3). In its iconographic composition, the group clearly reflects a developmental phase of the Xuanzang legend which was finally codified and popularised in the novel Xiyou ji 西遊記 [Record of the Journey to the West], ${ }^{5}$ composed

4 On Tangut Buddhism and Mt. Wutai, see Russell-Smith, Uygur Patronage in Dunhuang, 215221; Kirill Solonin, "Tangut Chan Buddhism and Guizang Zong-mi," Zhonghua foxue xuebao 中華佛學學報 [Chung-Hwa Buddhist Journal] 11 (1998): 365-424.

5 On the Xiyou ji and its complex history of antecedents, its development and research history, see Jaroslav Prušek, "The Narrators of Buddhist Scriptures and Religious Tales in the Sung Period," Archiv Orientální 10.1-2 (1938): 375-389; Glen Dudbridge, "The Hundred-Chapter Hsi-Yu Chi and Its Early Versions," Asia Major New Series 14.2 (1969): 141-191; Glen Dudbridge, 


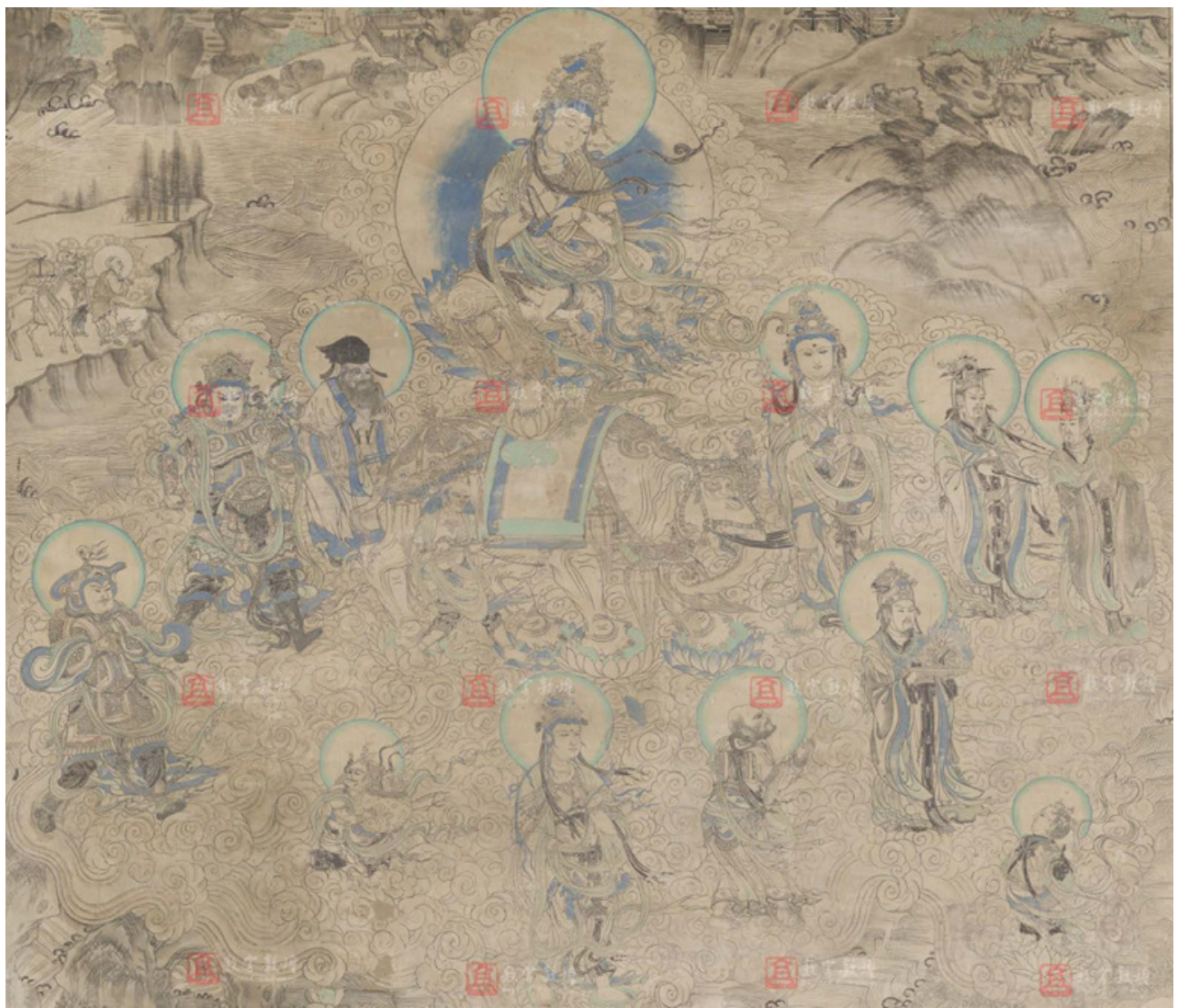

FIGURE 9.1 Samantabhadra. Yulin Cave 3, ca. 12th/13th c.

(c) MogAo GROTtoEs, DUNHUANG, GANSU, CHINA

during the Ming Dynasty (1368-1644, 明) and attributed to Wu Cheng'en (ca. 1500-1582, 吳承恩). It clearly reflects the stage that the legend had reached at the time of the Song Dynasty (96o-1279, 宋), from which it must have been transferred to a Tangut context. The existence of a still nameless proto-Sun Wukong (孫悟空), referred to as monkey-traveller (Chin. hou xingzhe 猴行者) (and the horse loaded with the sacred scriptures), is clearly indicated in the earliest sources of the story as, for example, the so-called Kōzan-ji-Xiyou ji 高山 寺-西遊記 [Record of the Journey to the West from the Kōzan Temple] which actually consists of two very similar texts, the Datang sanzang qujing shihua 大

The Hsi-yu chi: A Study of Antecedents to the Sixteenth-Century Chinese Novel (London, New York: Cambridge University Press, 1970); and Victor Mair, "Suen-Wu-Kung = Hanumat?," in: Zhongyang yanjiuyuan dierjie guoji hanxue huiyi lunwenji, Wenxuezu 2 中央研究院第二屆 國際漢學會議論文集文學組 2 Proceedings of the Second International Conference on Sinology, Section Literature (Taibei: Zhongyang yanjiuyuan, 1986), 659-752. 


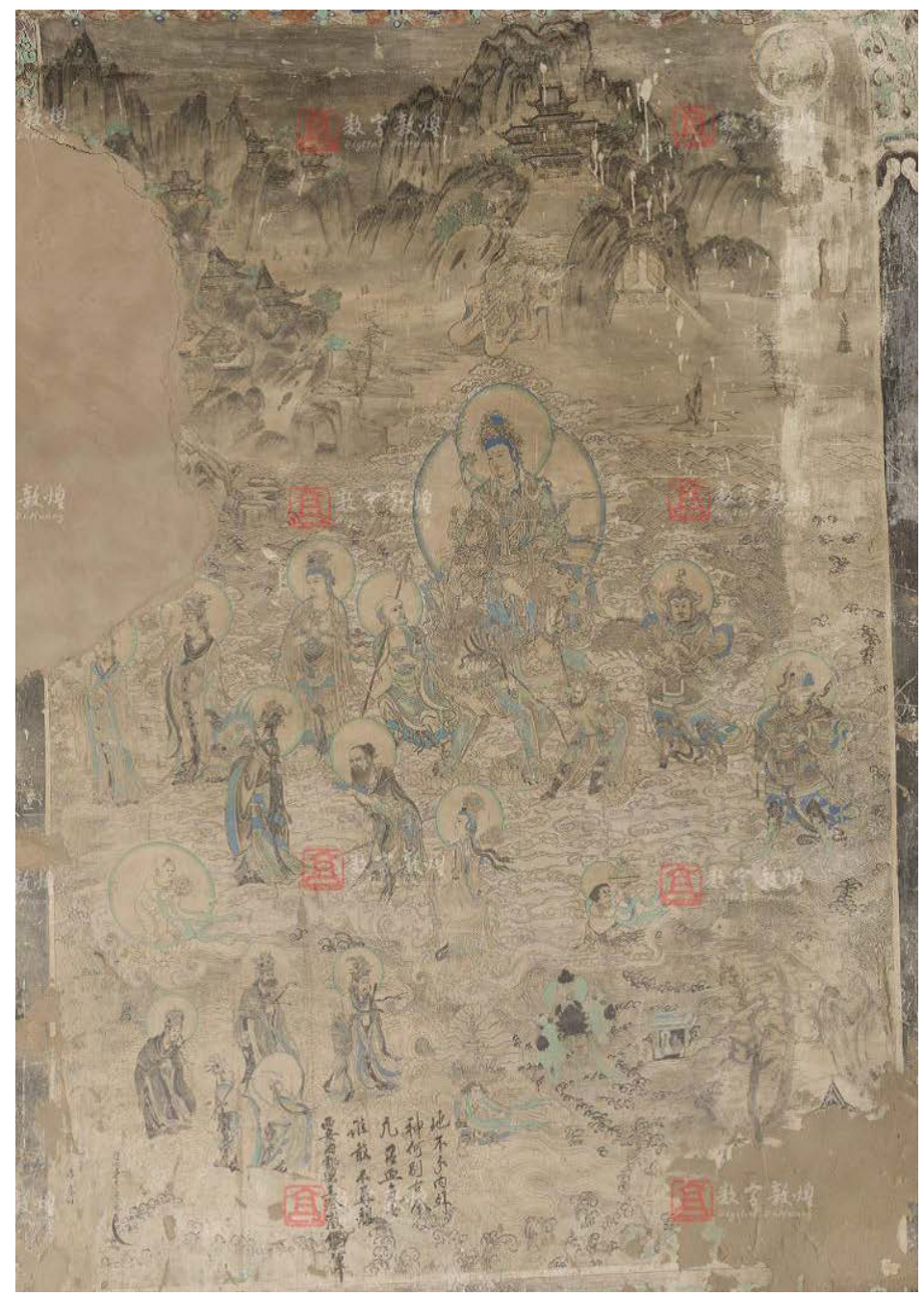

FIGURE 9.2 Mañjuśrī. Yulin Cave 3, ca. 12th/13th c.

(C) Mogao grottoes, DUNHUANG, GANSU, CHINA

唐三藏取經事話 (or shihua 詩話) [Story of the Matter of Tripitaka Fetching the sütras from the Great Tang] or the Datang sanzang fashi qujing ji 大唐三藏 法師取經記 [Record of the Dharma-Master Tripițaka Fetching the sūtras from the Great Tang]. ${ }^{6}$

In those texts, a certain focus lies on Xuanzang's and monkey's return, and this seems to be the scene depicted in the diptych. In chapter fifteen of the

6 I am using the electronic version of the text available at $<$ https://zh.wikisource.org/zhhant/大唐三藏取經詩話>. 


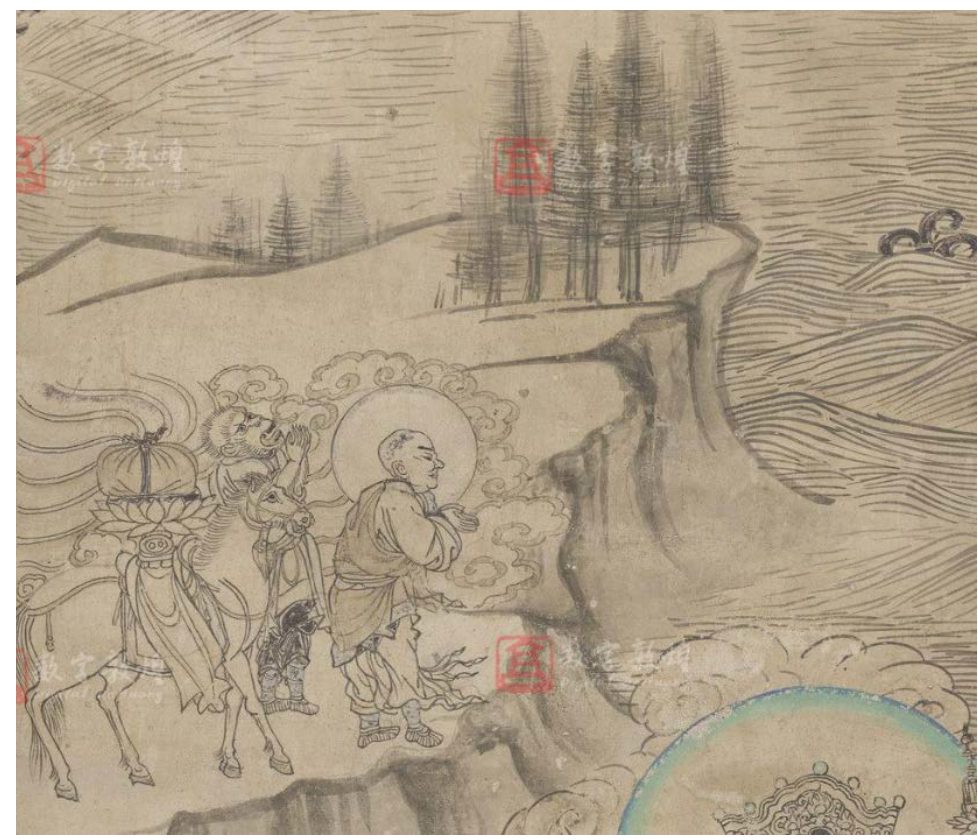

FIGURE 9.3 Detail of figure 9.1, Xuanzang and proto-Sun Wukong. Yulin Cave 3, ca. 12 th $/ 13$ th c.

(C) MOGAO GROTTOES, DUNHUANG, GANSU, CHINA

Story of the Matter of Tripitaka Fetching the sütras from the Great Tang, entitled Ru Zhuguo duhai zhi chu 入竺國度海之處 [On the Entering of the Kingdom of India and the Crossing of the Ocean], it is clearly described how the horse ${ }^{7}$ is loaded with the sacred scriptures before returning to China. ${ }^{8}$ The lotus pedestal

7 This horse is the white horse (Chin. baima 白馬) which the queen of the kingdom of the women gave to Xuanzang in a previous (tenth) chapter Jingguo Nüren guo chu 經過女人 國處 [On the Passing Through the Kingdom of Women]. Japanese paintings from the Kamakura Period (1185-1333, 鎌倉時代) depict the itinerant monk in a similar wayto the one in Yulin Cave 3, but without the horse: Dorothy Wong, "The Making of a Saint: Images of Xuanzang in East Asia," Early Medieval China 8 (2002): 63. For other representations of Xuanzang, see Asahi Shinbun 朝日新聞, Saiyūki no Shiruku Rōdo: Sanzō hōshi no michi 西遊記のシルクロード: 三蔵法師の道 [The Silk Road and the World of Xuanzang] (Osaka: Asahi Shinbun, 1999).

8 三藏頂禮, 點檢經文五千四十八卷, 各各俱足, 只無《多心經》本。法師收 拾, 七人扶持, 牽馬負載, 起程回歸告辭。竺國僧眾, 合城盡皆送出, 祝付 法師回程百萬, 經涉艱難, 善爲攝養, 保護玄文; 回到唐朝, 作大利 益。"[Master] Tripițaka paid reverence, checked the 5418 fascicles of sutras [and] each of them was complete [but] only a copy of the [Prajñāpārami]tāhrrdaya-sūtra was miss- 


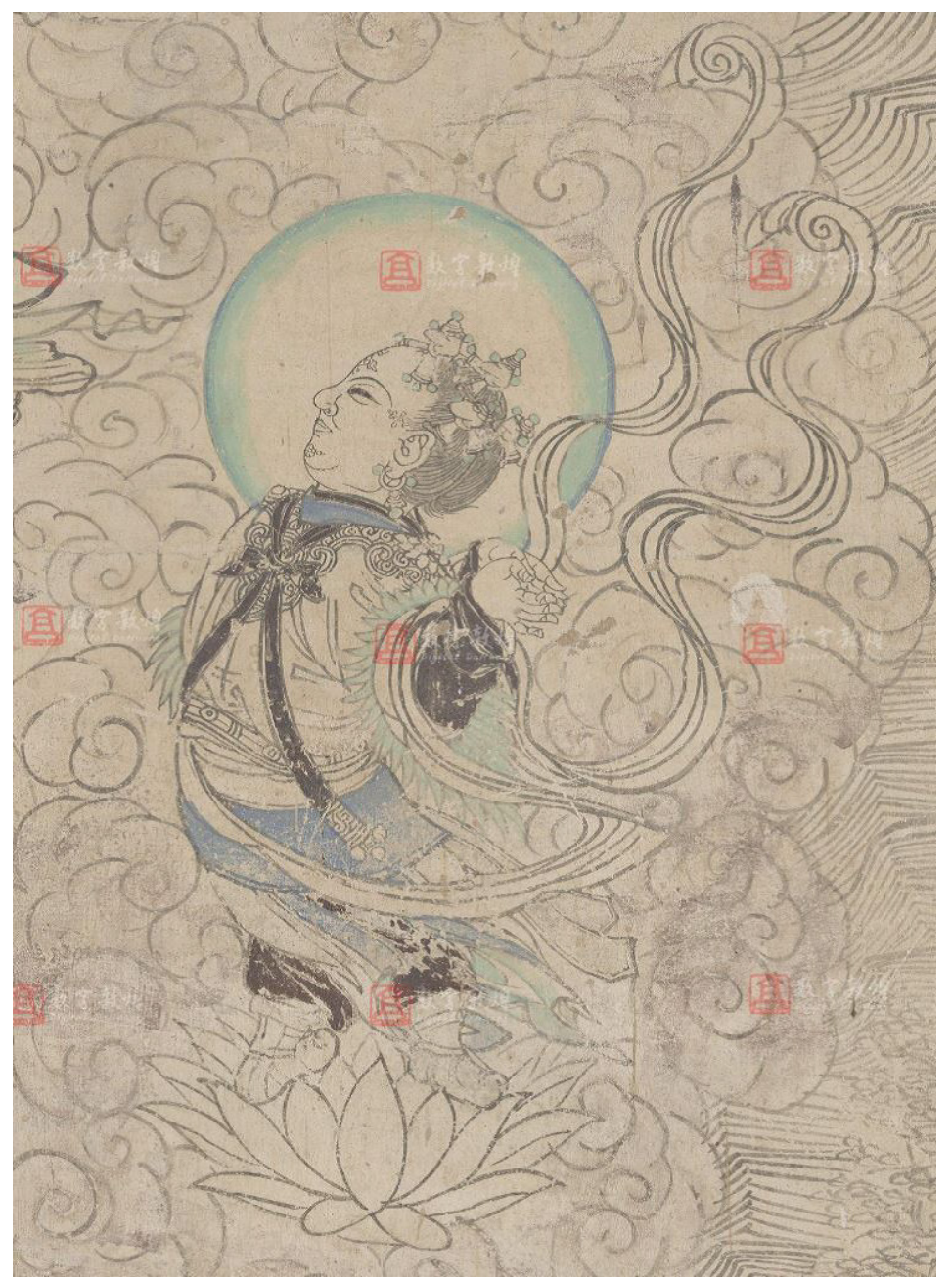

FIGURE 9.4 Detail of figure 9.1, Suddhana. Yulin Cave 3, ca. 12th/13th c.

(C) Mogao GRotToes, DUNHUANG, GANSU, CHinA

ing. The dharma master arranged [the sūtras], [his] seven companions assisted [him] and loaded one after the other on a horse in preparation for [their] return, [and they] took their leave. All the monks of the kingdom of India came out of the city to bid [him] farewell, wished the dharma master well for his return over millions [of miles] through hardship, [that he] kept up his health and took care of the mysterious texts; [when he would] have returned to the court of the Tang this would be of great benefit." My translation differs from Charles J. Wivell, "The Story of How the Monk Tripițaka of the Great Country of T'ang Brought back the Sūtras," in The Columbia Anthology of Traditional Chinese Literature, ed. Victor Mair (New York: Columbia University Press, 1994), 1200. 
bearing the sütras on the back of the horse in the painting may refer to the complete collection after the Prajñāpāramitāhrdayasūtra (Chin. Xinjing 心經) [Heart sütra] had been added in the next episode of the Zhuanzhi Xianglin sishou xinjing ben 轉至香林寺受心經本 [Arriving at the 'Fragrant Grove Monastery' and Receiving a Copy of the 'Heart sūtra']. ${ }^{9}$

Having clarified the context from which the small group of Xuanzang, the monkey and the horse originated, the connection with Samantabhadra and Mañjuśri is still unclear. Dorothy Wong has tried to interpret the painting in connection with the Gandaryūhasütra and supposes that "Xuanzang has assumed the role of the prototypical pilgrim Sudhana in his ultimate meeting with Samantabhadra."10 Besides the fact that there is no textual evidence of such a connection, this is internally contradicted by the presence of Sudhana in the painting, which obviously has escaped Wong's attention.

As it is a Song-period legend of Xuanzang and his monkey companion which is reflected in their appearance in the painting, it seems to be plausible to look for a connection between the bodhisattva(s) and the two pilgrims in this very narrative tradition and the two paintings. Unfortunately, neither Samantabhadra nor Mañjuśri appear in the extant Song story, the Story of the Matter of Tripițaka Fetching the sütras from the Great Tang.

However, the fact that the monk and the monkey in the painting are venerating at least one of the two bodhisattvas (i.e. Samantabhadra) - who always appear as a pair in the extant Ming Dynasty Record of the Journey to the Westseems to point to a version of the narrative in which Xuanzang and his accompanying monkey already had a connection with the bodhisattvas. In the extant Record of the Journey to the West, this connection is particularly the sub-narrative of chapter 77, Qunma qi benxin yiti bai zhenru 群魔欺本性 一體拜真如 [The Crowd of Demons Deceive the Fundamental Nature-One Body Pays Reverence to the True Nature]. Previously Xuanzang—Tang seng (唐僧)—and his companions have been captured by three demons: two of them Mañjuśri's and Samantabhadra's transformed vehicles, the elephant Xiangwang (象王) or Baixiang (白象) and the lion Shiwang (獅王) or Qingshi (青獅). When the monkey Sun Wukong is not able to free them, he travels through the air to India (Chin. Tianzhu 天竺), to Mt. Gṛdhrakūța (Chin. Jiufeng shan 熟峰山), to ask the tathāgata (Chin. rulai 如來) for help. The tathāgata summons his

9 On the link between the Prajñāpāramitährdayasūtra and Xuanzang in Buddhist art, see Wong, "The Making of a Saint," 63 and fig. 8. The paintings of the "Prajñā assembly" (Wong) interestingly represent Mañjuśrī, Samantabhadra and Xuanzang. Ibid., 72. 
disciples Ānanda (Chin. A'nan 阿儺) and Kāśyapa (Chin. Jiaye 迦葉) to get Mañjuśrí (Chin. Wenshu 文殊) from Mt. Wutai (Chin. Wutai shan 五臺山) and Samantabhadra (Chin. Puxian 普賢) from Mt. Emei (Chin. Emei shan 峨眉山), and all together they fly to the place where the monk and his companions are captured, subdue the demons-Mañjuśrīs and Samantabhadra's own animals ${ }^{11}$ — and free the monk and his companions.

It seems to me that a prototype ${ }^{12}$ of this very sub-episode in the Record of the Journey to the West from the Song period may be the underlying motif for Xuanzang's and the monkey's presence in the compositional framework, obviously already known to the Tanguts. ${ }^{13}$ I would suggest the following interpretationadmittedly hypothetical because it is not found in any textual version-: the scene in the painting represents Xuanzang and the monkey on their way back from India when they pay respect to the two bodhisattvas because they previously had helped rescue them from being killed by the animals turned into demons.

To be sure, this interpretation does not necessarily invalidate Michelle McCoy's statement that Xuanzang appears here to 'authenticate' the scenery. She may draw her authority from two different contexts: one as the 'connoisseur' of Buddhist sacred landscape beyond the Sinitic sphere-as a traveller or pilgrim, as it were - and another one, more specific, from the emerging legendary narrative finally developing into the Record of the Journey to the West as it was brought in literary form in the Ming Dynasty.

卻被文殊、普賢念動真言, 喝道：“這蔁畜還不的正, 更待怎生？”諕得老 怪、二怪不敢撑持, 至了兵器, 打個滾, 現了本相。二菩薩將蓮花臺拋在那 怪的脊背上, 飛身跨坐, 二怪逐泯耳敀依。“But Mañjuśrī and Samantabhadra recited magical spells and shouted: 'These beasts still do not return to rightness-what are [they] waiting for?' They intimidated the two monsters [in a way that] they did not dare to resist, dropped [their] weapons, rolled around and displayed [their] original characteristic marks. The two bodhisattvas took their lotus pedestals, threw them on the back of the monsters and flew to sit on [them], [so that] the two monsters finally just disappeared and were converted [to their former tamed form]." Text quoted after Wikisource, “西遊記/第077回," accessed October 6, 2018. <https://zh.wikisource.org/wiki/西遊記/ 第077回>. See also the translations in William J.F. Jenner, Journey to the West, 3 vols. (Beijing: Foreign Languages Press, 1982-1986) and Anthony C. Yu, The Journey to the West (Revised Edition), 4 vols. (Chicago, London: The University of Chicago Press, 2012). Another proto-narrative is reflected in an album from the Yuan Dynasty (1279-1368, 元), in which Xuanzang is much more proactive-e.g. subduing demons - than in the extant Xiyou ji. See Wong, "The Making of a Saint," 75 and fig. 18.

Xinjiang Rong, Eighteen Lectures on Dunhuang (Leiden, Boston: Brill, 2013), 481. 
More evident is the link between Sudhana kumāra (Chin. Shancai tongzi 善財 童子) and Samantabhadra (fig. 9.4): this is a clear reference to the Avatamsakasütra, which held much popularity in Tangut Buddhism, ${ }^{14}$ or more specifically, to the last section of the enormous Gandaryūhasūtra containing Sudhana's famous pilgrimage on his quest for knowledge. ${ }^{15}$ After having visited spiritual advisors (Skt. kalyānamitra, Chin. shanzhishi 善知識), guided by Mañjuśrī, he finally receives the teaching by Samantabhadra. ${ }^{16}$ The depicted scene then represents this final stage of Sudhana's quest for wisdom when he has reached Samantabhadra, perhaps, as indicated by his bodily position, coming from Mañjuśri depicted on the other painting of the diptych. Sudhana has therefore reached the end of his physical and spiritual journey, as Xuanzang has accomplished his task of bringing back the sacred scriptures of Buddhism to China, depicted in the opposite corner of the painting. It seems that the shared themes between the presence of the two figures, Xuanzang and Sudhana, are pilgrimage and a ritualised landscape in which the two bodhisattvas, Samantabhadra and Mañjuśrī, had a position and place of their own in an imagined Buddho-Indian topography. ${ }^{17}$

14 See e.g. Kirill Solonin, "The Glimpses of Tangut Buddhism," Central Asiatic Journal 52.1 (2008): 72 .

15 For East Asian representations of Sudhana's pilgrimage, see Shunshō Manabe, "The Development of Images Depicting the Teaching of the Avatamsaka-sūtra," in Avatamsaka Buddhism in East Asia: Origins and Adaption of a Visual Culture, ed. Robert Gimello Frédéric Girard, and Imre Hamar (Wiesbaden: Harrassowitz, 2012), 205-221; and Dorothy Wong, "The Art of Avatamsaka Buddhism at the Courts of Empress Wu and Emperor Shōmu/Empress Kōmyō," in Avatamsaka Buddhism in East Asia: Origins and Adaption of a Visual Culture, ed. Robert Gimello, Frédéric Girard, and Imre Hamar (Wiesbaden: Harrassowitz, 2012), 222-26o; for a discussion of South Asia (Borobudur), see Jan Fontein, Entering the Dharmadhātu: A Study of the Gandaryūha Reliefs of Borobudur (Leiden, Boston: Brill, 2012); and for an example from the Tibetan tradition (from Tabo/Tha po), see Ernst Steinkellner, Sudhana's Miraculous Journey in the Temple of Ta pho. The Inscriptional Text of the Tibetan Gandaryūha Edited with Introductory Remarks (Rome: Istituto Italiano per il Medio ed Estremo Oriente, 1995).

16 For this last stage of Sudhana's journey from Mañjuśri to Samantabhadra, see Buddhabhadra's (359-429) translation T. 278.9, 783b27, and Śikșānanda's (562-710) translation T. 279.9, 439b6. For an English translation of the Śikșānanda version, see Thomas Cleary, The Flower Ornament Scripture: A Translation of the Avatamsaka Sutra (Boston, London: Shambala, 1993), 1503 .

17 In this context, one could ask if such a connection - the one of a paradigmatic pilgrimis not reflected in the existence of Song Dynasty (960-1279, 宋) Datang sanzang qujing shihua at the Kōzan Temple, a temple closely connected with Myōe (1173-1232, 明恵), one of the most eminent exponents of the Avatamsaka tradition in the Japanese medieval 
Although it is not surprising in the context of medieval Buddhist art that Samantabhadra and Mañjuśrī are paired together, the periphery of the Mañjuśrī painting raises interesting interpretational questions. At the conference, Michelle McCoy rightfully pointed out the specific feature of water landscape, particularly the dramatic streaming or pouring down of water from a cleft in the mountains in the Mañjuśrī painting (fig. 9.5). She linked this motif to water control and suggested that it reflects elements from the post-Tang Dynasty (618-907, 唐) foundation legend from Khotan, according to which Vaiśravana and Śāriputra drained a primordial lake by cutting its shore. ${ }^{18}$ The links to this narrative in the painting - apart from the king of Khotan standing or walking in front of Mañjuśri ${ }^{19}$ — seem to be the monk with a bodhisattva's staff (Skt. kakkhara) in front of Mañjuśri (Śāriputra) and the armoured deity behind the bodhisattva (Vaiśravana ${ }^{20}$ (fig. 9.6). However, there is no indication that the water scenery is directly influenced by the Khotanese story in which no connection with Mañjuśrī is found. While Mañjuśrī and the Khotanese king are a relatively well-established iconographic element in Dunhuang from the 1oth century onwards, a direct link with the drainage motif is missing.

In light of what John Brough has already observed in his 1948 article "Legends of Khotan and Nepal"21 and my own research on Buddhist foundation

period. See e.g. Robert E. Morrell, "Kamakura Accounts of Myōe Shōnin as Popular Religious Hero," Japanese Journal of Religious Studies 9.2-3 (1982a): 171-198; and George J. Jr., Tanabe, Myōe the Dreamkeeper: Fantasy and Knowledge in Early Kamakura Buddhism (Cambridge Mass., London: Harvard University Press, 1992), 122. Of Myōe, we also know that he was very much interested in pilgrimage, particularly to India and with reference to Xuanzang: Robert E. Morrell, "Passage to India Denied: Zeami's Kasuga Ryūjin," Мonumenta Nipponica 37.2 (1982b): 179-200; Tanabe, Myōe the Dreamkeeper, 50; Bernard Faure, "Kegon and Dragons: A Mythological Approach to Huayan Doctrine," in Reflecting Mirrors: Perspectives on Huayan Buddhism, ed. Imre Hamar (Wiesbaden: Harrassowitz, 2007), 300, 305-306.

For a detailed discussion of this and other 'drainage' legends in the wider Himalayan region, cf. Max Deeg, Miscellanae Nepalicae: Early Chinese Reports on Nepal-The Foundation Legend of Nepal in its Trans-Himalayan Context (Lumbini: Lumbini International Research Institute, 2016); on Khotan, see p. 113.

19 Qiang Ning, Art, Religion, and Politics in Medieval China: The Dunhuang Cave of the Zhai Family (Honolulu: University of Hawai'i Press, 2004), 103f; Christoph Anderl, "Linking Khotan and Dūnhuáng: Buddhist Narratives in Text and Image," Entangled Religions: Interdisciplinary Journal for the Study of Religious Contact and Transfer 8 (2018): 30. On the presence of this legend in Dunhuang, see now Ning, Art, Religion, and Politics in Medieval China, 92, and Anderl, "Linking Khotan and Dūnhuáng," 33.

21 John Brough, "Legends of Khotan and Nepal," Bulletin of the School of Oriental and African Studies, University of London 12.2 (1948): 333-339. 


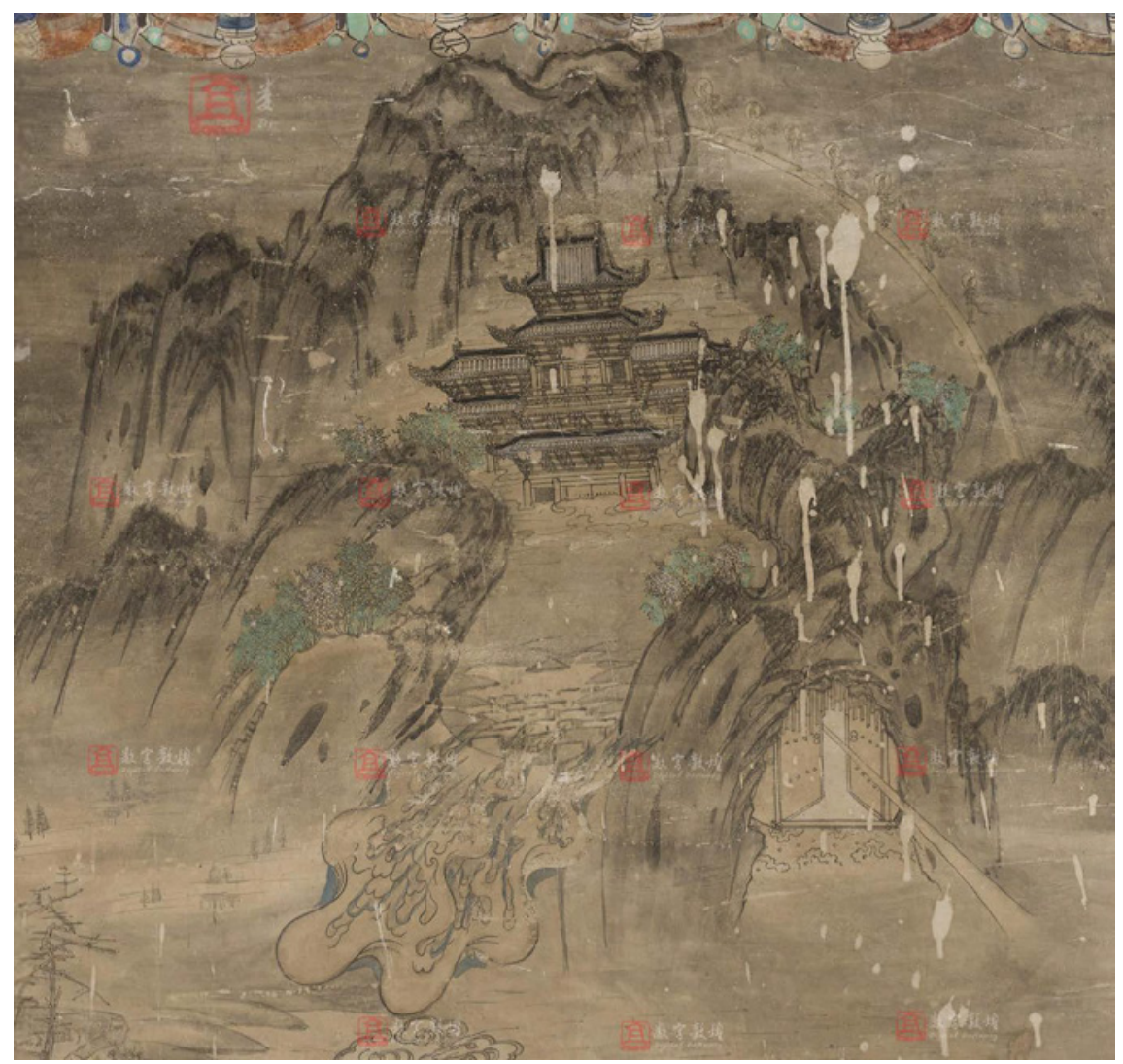

FIGURE 9.5 Detail of figure 9.2, drainage scene. Yulin Cave 3, ca. 12th/13th c.

(C) MOgAo GRotToEs, DUNHUANG, GANSU, CHINA

legends along the wider Himalayan range, ${ }^{22}$ I would push this point a little bit further, even though it may appear somewhat speculative. While I do not know of any legend in which Samantabhadra is connected to water and its regulation, Mañjuśri is clearly the main agent in one of the major drainage narratives in the Himalayan region. It is the Nepalese Buddhist story of Mañjuśrī cutting a hole into the mountains with his sword to release the water from the primordial lake in the Kathmandu Basin, populated by nägas and flooding the light of the Svayambhū, which is recorded in its oldest form in the shorter version of the Newar Buddhist Svayambhü-purāna. ${ }^{23}$ The scene clearly shows a valley encompassed by high mountains and a building in the centre of the valley which

22 Deeg, Miscellanae Nepalicae.

23 Ibid., 162. 


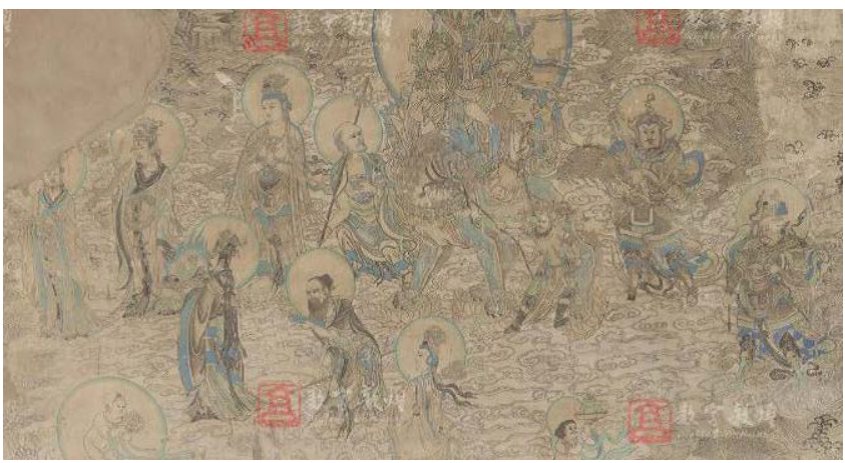

FIGURE 9.6

Detail of figure 9.2,

Mañjuśrī and his entourage. Yulin Cave 3 , ca. 12 th/13th c. (C) MOGAO GROTTOES, DUNHUANG, GANSU, CHINA

might well be, in this case, a sinicised version of the Svayambhū-caitya (fig. 9.5). All of these features do not really fit the Khotanese narrative but, rather, the Nepalese legend.

While it is obvious that the extant Nepalese legend itself has been influenced by the Chinese idea that Mañjuśri is residing on the Five-Peak-Mountain, Mt. Wutai (Skt. Pañcaśikhaparvata), ${ }^{24}$ the extant Mt. Wutai legends from China do not contain any element regulating or controlling water except the constant emphasis of Mañjuśri's role as the poisonous nāgas (Chin. dulong 毒龍). ${ }^{25}$ Thus, however this may be explained historically, the diptych's focus on water and its flow-if it has anything to do with the two major bodhisattva figures and if it is more than a pure water landscape-is clearly influenced by a story similar to the Nepalese one (and maybe others, some of which are unknown). It is only in the Nepalese narrative that Mañjuśrī acts as a central figure. One possibility is, of course, that the painter(s) combined the well-known combination of the Khotanese king and Mañjuśrī with the other famous Khotanese motif, the drainage of the primordial lake through Śāiputra and Vaiśravana. What is missing, however, is the link with Mt. Wutai, Mañjuśri’s residence in China.

There is another point that makes such a connection between the painting and the Nepalese legend (or a similar one) even more likely - the presence of both Mt. Wutai (Skt. Pañcaśikhaparvata) and Mt. Gośirșa, Oxhead Mountain (Chin. Niutou shan 牛頭山, Skt. Gośīrșaparvata), respectively Mt. Gośrninga, Oxhorn Mountain (Chin. Niujiao shan 牛角山, Skt. Gośrnngaparvata), is only explainable in the wider Trans-Himalayan context of the ubiquitous mythological narrative of the foundation of the country through the drainage of a

24 Deeg, Miscellanae Nepalicae, 178.

25 Ibid., 181. 
primordial lake which is therefore neither flooding nor damming. It is the Nepalese story's link to Mt. Wutai which makes the link most plausible. The Khotanese nomenclature of the Oxhorn and Oxhead Mountain clearly is influenced by the Gośrnga (Oxhorn) or Gopucchaparvata (Oxtail Mountain) in the Nepalese story; but Mt. Wutai is not playing any role in this story. It then may have been the common motif of the drainage of the primordial lake which prompted the artist(s) to make a connection-almost intuitively-between the Khotanese and the Nepalese narratives of draining a primordial lake.

Furthermore, the fact that the Oxhead Mountain playing such an important role in the Khotanese narrative is also found in the Chinese Avatamsaka tradition $^{26}$ may explain the combination of Mañjuśrī and Samantabhadra in the diptych, the two bodhisattvas who figure so prominently as a complementary pair in the Avatamsakasūtra. The mountain may be the logical narrative link to the drainage motif in the Mañjuśrī painting. Historically, a Nepalese-Tangut connection, maybe through Tibet, ${ }^{27}$ cannot be excluded as the origin of the particular iconography in Yulin Cave 3. The artist(s), in this case, would have woven together many different strands of legends and motifs into the incredibly dense patchwork of elements and motifs in the diptych.

\section{5}

\section{Conclusion}

In light of the wider artistic programme of the cave, I am tempted to speculate about the position and function of the diptych to the left and right of the entrance as a passage through the mountainous areas into, or from, the more central Buddha realm inside the cave, represented by the programmes of the other paintings in the same cave; for example, scenes from the life of the Buddha, from the Vimalakirtisütra, the Pure Land of the Buddha Amitāyus. Traveling in and access to a sacred space, an imagined and idealised 'India' of the Buddha and Vimalakirti or Buddha land, could well be represented by the two paintings at the side of the entrance to the cave- the peripheral figures of $\mathrm{Xu}$ anzang and Sudhana only underlining and making recognisable this very idea.

If the diptych really is the result of an amalgamation process of motifs and narrative elements from such different periods and regions as my suggested interpretation implies, then it obviously represents very well the Buddhist

\footnotetext{
26 Deeg, Miscellanae Nepalicae, 123 note 525.

27 Ronald M. Davidson, Tibetan Renaissance: Tantric Buddhism in the Rebirth of Tibetan Culture (New York, Chichester: Columbia University Press, 2004), 281.
} 
nodes thematically framing the topic of the present volume, which allowed new Buddhist clientele - the Tangut patrons - to reformulate successfully already existing concepts, elements and narratives from different but still entangled regions for the sake of creating their own form of Buddhist identity. 